\title{
Size-Specific, Dynamic, Probabilistic Material Flow Analysis of Titanium Dioxide Releases into the Environment
}

\author{
Yuanfang Zheng and Bernd Nowack*
}

Cite This: Environ. Sci. Technol. 2021, 55, 2392-2402

Read Online

ABSTRACT: Most of the existing exposure models for engineered nanomaterials (ENMs) do not consider particle size, crystalline forms, and coating materials that all may influence the material's fate, transport, and toxicity. Our work aimed to incorporate particle size distributions into a material flow analysis (MFA) to develop a sizespecific, dynamic, probabilistic MFA model (ss-DPMFA). Using titanium dioxide $\left(\mathrm{TiO}_{2}\right)$ as a first case study, we aimed to determine the contribution of conventional $\mathrm{TiO}_{2}$ pigments to the total amount of nanoscale $\mathrm{TiO}_{2}$ released into the environment. Besides providing information on mass flows, the new model used particle size distributions and crystalline forms to describe the stocks and flows of $\mathrm{TiO}_{2}$. The most striking modeling result to emerge was that before $\mathrm{TiO}_{2}$ ENMs came onto the market as such in 2000, 22,400 tons of

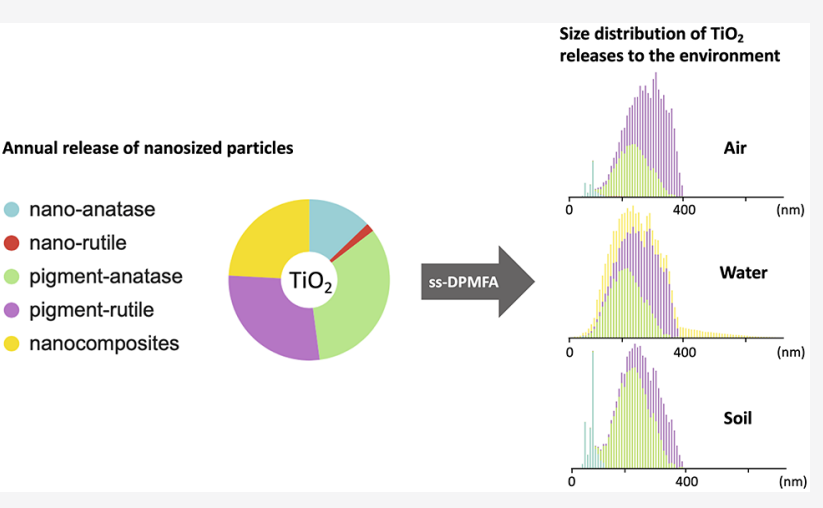
nanosized $(<100 \mathrm{~nm}) \mathrm{TiO}_{2}$ particles had already been released into the environment, originating from conventional $\mathrm{TiO}_{2}$ pigments. Even in 2016, 50\% of the nanosized $\mathrm{TiO}_{2}$ particles released into wastewater came from the nanosized fraction of $\mathrm{TiO}_{2}$ particles in pigments. Quantitative data on the particle size distribution of $\mathrm{TiO}_{2}$ particles released into the environment can be used as input for environmental fate models. Our new ss-DPMFA model's additional insights about crystalline forms and coatings could pave the way for advanced size- and form-specific hazard and risk assessments for other nanomaterials in ecological systems.

\section{INTRODUCTION}

Since 1918, titanium dioxide $\left(\mathrm{TiO}_{2}\right)$ has been produced and developed on an industrial scale as a white pigment. ${ }^{1,2} \mathrm{TiO}_{2}$ is the most widely produced white pigment, with worldwide production for 2020 estimated to be 7 million tons. ${ }^{3} \mathrm{TiO}_{2}$ is primarily used in paints and coatings, plastics, paper, printing inks, cosmetics, and food (as E171). Its added value lies in its outstanding light-scattering abilities and its resistance to weather, low toxicity, and chemical and biological inertness. ${ }^{4,5}$ These properties are closely related to its primary particle size distribution, crystalline form, and surface treatment. ${ }^{6}$

$\mathrm{TiO}_{2}$ pigment's light-scattering ability is maximal in particles between 200 and $350 \mathrm{~nm}$ in size, and most commercially available pigments are produced within this range. ${ }^{4}$ Two of the most widely used, commercial, crystallographic, bulk material configurations of $\mathrm{TiO}_{2}$ are anatase and rutile. Rutile pigments are more resistant to weathering and make products more opaque than anatase pigments do. ${ }^{4,7}$ Less stable anatase pigments are chosen for products such as interior paints because they are cheaper. ${ }^{8}$ To enhance their dispersibility within a matrix and improve weather resistance, $\mathrm{TiO}_{2}$ pigment surfaces are generally given inorganic and organic coatings. ${ }^{6}$

Engineered nano- $\mathrm{TiO}_{2}$ has been produced on an industrial scale since the 2000 s, with an estimated worldwide production of 68,000 tons in $2016 .^{9}$ Materials with $50 \%$ or more of their primary particles in the $1-100 \mathrm{~nm}$ size range are defined as nanomaterials. ${ }^{10}$ Apart from the difference in size, nano- $\mathrm{TiO}_{2}$ is transparent and cannot scatter visible light but retains its ability to absorb UV light. ${ }^{11} \mathrm{Nano}-\mathrm{TiO}_{2}$ 's applications can be divided into two categories, based on their crystalline form: UV light filters in their rutile form and photocatalysts or semiconductors in their anatase form. Nano-anatase is more photoactive than the rutile form due to its lower lightscattering abilities, a higher refractive index, and its better absorption of UV radiation. ${ }^{12}$ Nano-anatase is mostly found in self-cleaning coatings and solar cells. ${ }^{5}$ Nano-rutile is used widely as a UV light stabilizer in sunscreens, plastic-based products, and textiles, due to its lower photocatalytic activityactivity that could destroy a surrounding organic matrix. ${ }^{11}$ The particle structure of nano- $\mathrm{TiO}_{2}$ used in sunscreens is different from that used in other applications. ${ }^{13,14}$ Instead of bare nanoparticles, they are used in the form of coated nano-

Received: November 4, 2020

Revised: January 18, 2021

Accepted: January 19, 2021

Published: February 4, 2021

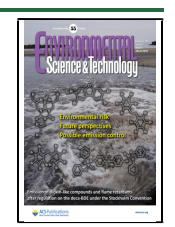


composites. Clusters of 2-6 units of single particles form a $\mathrm{TiO}_{2}$ core coated with aluminum oxide, silica, or another material, which eliminates the photocatalytic effect of UV radiation, and with an organic coating for better dispersion within an organic matrix.

From a toxicological perspective, $\mathrm{TiO}_{2}$ pigment products did not draw much attention until the presence of nanoparticulate $\mathrm{TiO}_{2}$ was confirmed, especially in food products where it is applied as E171 in Europe. ${ }^{15,16}$ Several studies found that 10$36 \%$ of the $\mathrm{TiO}_{2}$ particles in food products were smaller than $100 \mathrm{~nm} .^{16-20}$ After digestion by humans, most $\mathrm{TiO}_{2}$ particles in food products are excreted in feces and enter the wastewater treatment system. Wastewater treatment plants (WWTPs) capture the majority of both microsized and nanosized $\mathrm{TiO}_{2}$ particles in their sludge, but a small fraction will be released into surface waters via WWTP effluents. ${ }^{21}$

The toxicity and fate of nanomaterials in the environment depend on various physicochemical characteristics such as particle size, crystalline form, and surface treatment. ${ }^{22,23}$ Nanosized $\mathrm{TiO}_{2}$ particles are more photoactive and thus more phototoxic than microsized $\mathrm{TiO}_{2}$ particles. ${ }^{22,24}$ Nanoanatase has been found to be 100 times more toxic than nanorutile because it generates more reactive oxygen species (ROS). ${ }^{25}$ Jiang et al. analyzed the different impacts of crystalline form and particle size on oxidant capacity under controlled conditions. ${ }^{26}$ They observed that ROS generation per unit surface was a function of particle size for the same crystalline form of $\mathrm{TiO}_{2}$ nanoparticles. The nano- $\mathrm{TiO}_{2}$ used in sunscreens, and coated with $\mathrm{Al}$ or $\mathrm{Si}$ to inhibit the formation of ROS, was found to be much less toxic than uncoated, foodgrade $\mathrm{TiO}_{2}{ }^{27,28}$

Detecting and quantifying $\mathrm{TiO}_{2}$ engineered nanomaterials (ENMs) and pigments in complex natural environments remains a significant challenge. This is due to the similar elemental compositions of engineered and natural nanoparticles, and to the high background concentrations of natural (nano)materials and low concentrations of engineered particles in the environment. ${ }^{29,30}$ Recently, single-particle inductively coupled plasma mass spectrometry has been used to differentiate $\mathrm{TiO}_{2}$ ENMs from natural particles in surface water. ${ }^{29,31}$ Engineered $\mathrm{TiO}_{2}$ particles ranging from a few tens to a few hundreds of nanometers across were detected in surface water, runoff from exterior facades, and leachates from construction and demolition landfill sites. ${ }^{32-34}$ The majority of $\mathrm{TiO}_{2}$ in stormwater was present either as pigment-sized particles or as aggregates of ENMs. ${ }^{35}$

Material flow analysis (MFA) is an environmental exposure modeling tool used to quantify material flows through the technosphere and their release into the environment. ${ }^{36}$ A range of different MFA models has been used estimate the release of several ENMs into the environment for different geographic regions and with various levels of details, using both static ${ }^{37-41}$ and dynamic ${ }^{42,43}$ models. To date, most MFA models for ENMs have only considered a generic ENM; i.e., they lumped of different nanoforms of the material together. A few studies have classified nano- $\mathrm{TiO}_{2}$ into different categories according to functionality, crystalline form, and form of release. Gottschalk et al. modeled flows of photocatalytic $\mathrm{TiO}_{2}$ and photostable $\mathrm{TiO}_{2}$ separately. ${ }^{44}$ Wigger and Nowack allocated separate total nano- $\mathrm{TiO}_{2}$ flows to the anatase and rutile forms based on product functionalities. ${ }^{45}$ Adam et al. modeled released nano$\mathrm{TiO}_{2}$ in its pristine, matrix-embedded, transformed, and product-embedded forms. ${ }^{46}$ All these modeling studies revealed that the form of nano- $\mathrm{TiO}_{2}$ had a substantial impact on its environmental release. Moreover, Sun et al. compared material flows for nano- $\mathrm{TiO}_{2}$ and $\mathrm{TiO}_{2}$ pigment. ${ }^{21}$ None of the studies mentioned above, however, considered the particle sizes of $\mathrm{TiO}_{2}$ in their modeling, or the contribution of the nanosized fraction of $\mathrm{TiO}_{2}$ pigment to the total release of nano- $\mathrm{TiO}_{2}$.

The present study, therefore, aims to integrate the size distribution of the particle flows into the MFA. A new method is applied to determine the contribution of nanosized particles from conventional $\mathrm{TiO}_{2}$ pigments to the total amount of nanoscale $\mathrm{TiO}_{2}$ released into the environment, and a distinction is made between the different forms of $\mathrm{TiO}_{2}$ (rutile, anatase, with and without coating).

\section{METHODS}

ss-DPMFA Model. The size-specific, dynamic, probabilistic, MFA (ss-DPMFA) model computes size information about the particle flows released into the environment. This new method was built based on an established algorithm-the dynamic, probabilistic, MFA (DPMFA) - that has been used to model several ENMs. ${ }^{46-48}$ By employing Monte Carlo simulations, the probabilistic method can analyze the inherent uncertainty of all the parameters. Dynamics are modeled by considering the increase in the annual production over time and the release of materials over their entire life cycle. ${ }^{47}$ In recent years, significant improvements have been made to the DPMFA method, including adding the dynamics of transfer coefficients in solid waste and wastewater management over time. ${ }^{49}$ The general diagram of the ss-DPMFA model used in this study is shown in Figure S1.

Adam et al. added the forms of ENM release (pristine, matrix-embedded, transformed, product-embedded, and dissolved) into the static, probabilistic, MFA. ${ }^{46}$ The forms in which they are released into the environment are not only related to their product category but also to transformations they may undergo throughout their life cycle. We also added this aspect to the ss-DPMFA method and modeled it for nano$\mathrm{TiO}_{2}$ and $\mathrm{TiO}_{2}$ pigment separately. Since $\mathrm{TiO}_{2}$ is insoluble in water, the dissolved form was not considered in our case. The following four forms of release were considered:

(i) Pristine: Particles released in their original production form, neither embedded in a matrix nor transformed. Due to the lack of size information on aggregated or agglomerated particles during release processes, only the size distribution of the primary particles was modeled.

(ii) Matrix embedded: Particles are embedded in a solid matrix, such as paint, cement, or a polymer.

(iii) Transformed: The chemical composition of the particles is changed by a process such as incineration.

(iv) Product embedded: Particles that are still embedded in a product, e.g., a textile.

The model's input data include the production volumes of nano- $\mathrm{TiO}_{2}$ and $\mathrm{TiO}_{2}$ pigment over time, their shares in different product categories, and transfer coefficients between technical and environmental compartments. A probability distribution was built to incorporate the uncertainty in each of these parameters. Input data regarding releases from products during use and at end-of-life were extracted from the base model (Table S8). ${ }^{47}$ We included additional release information from products containing $\mathrm{TiO}_{2}$ pigments. We updated release data for indoor paints and distinguished 
between cosmetics regarded as nanoproducts and other cosmetics containing $\mathrm{TiO}_{2}$ pigments (see the Supporting Information, Sections 6.1 and 6.2). We used Rajkovic et al.'s latest data on solid waste management and wastewater management. ${ }^{49}$ Paper waste was not defined in the previous DPMFA study's waste category; therefore, we added a model on the fate of $\mathrm{TiO}_{2}$ during paper recycling and reprocessing (see the Supporting Information, Section 7). Other new data in the present model include production volumes, allocations to product categories, and size-specific WWTP efficiencies for nano- $\mathrm{TiO}_{2}$ and $\mathrm{TiO}_{2}$ pigments. The following sections describe data collection and processing methods.

Dynamics of Nano- $\mathrm{TiO}_{2}$ and $\mathrm{TiO}_{2}$ Pigment Production Volume. The temporal boundary for nano- $\mathrm{TiO}_{2}$ production was set from 2000-2016. We reinvestigated the most recent $\mathrm{TiO}_{2}$ ENM production data from market reports ${ }^{3,9}$ and the French nanoregistry. ${ }^{50}$ Future Markets Inc. ${ }^{9}$ collected data from leading $\mathrm{TiO}_{2}$ producers and provided global market data from 2010-2016. The European market's demand of $\mathrm{TiO}_{2}$ ENM is estimated to be $52 \%$ of the global total. ${ }^{9}$ We downscaled global demand for nano- $\mathrm{TiO}_{2}$ to Europe for 2010-2016 and built a triangular distribution for each year's production based upon reported low, conservative, and optimistic estimates. In 2013, France introduced the mandatory registration of ENMs. ${ }^{50}$ Its data repository is considered a reliable source of nano- $\mathrm{TiO}_{2}$ production volumes and a good reflection of the French market, one that can be used to estimate European demand. ${ }^{51}$ The estimated production of 42,100 tons of nano- $\mathrm{TiO}_{2}$ in Europe in 2013 is comparable with the European market's demand of 44,200 tons in the Future Markets Inc. report. ${ }^{9}$ Due to the absence of data before 2010, we multiplied the base year's production (2010) by Sun et al.'s retrospective scaling factor for ENM. ${ }^{47}$

We screened papers and studies reporting $\mathrm{TiO}_{2}$ pigment production and demand volumes (Table S2). Raw global-scale data were extrapolated to Europe based on Future Markets Inc.'s report that Europe's demand makes up 25\% of global demand. $^{3}$ We built a production probability distribution for the reference year of 2016 by combining all these data sources. To estimate $\mathrm{TiO}_{2}$ pigment production over time, annual retrospective and prospective scaling factors were summarized based on studies providing information on the evolution of $\mathrm{TiO}_{2}$ pigment production. By multiplying the reference year production probability distribution by the scaling factor for each year, we estimated the development of $\mathrm{TiO}_{2}$ pigment production in Europe from 1918-2020. The temporal boundary for modeling $\mathrm{TiO}_{2}$ pigment was set from 19702016. After the year 1970, all current products using pigment $\mathrm{TiO}_{2}$ were on the market and thus the assumption of no change in product distribution can be warranted.

Distribution to Product Categories. A decision tree (Figure S2) was created to allocate the total production of $\mathrm{TiO}_{2}$ to five different $\mathrm{TiO}_{2}$ forms: nano-anatase, nano-rutile, anatase pigment, rutile pigment, and nanocomposites. We assumed that these five forms are exclusively associated with specific product categories. Data sources on the product distribution of nano- $\mathrm{TiO}_{2}$ and $\mathrm{TiO}_{2}$ pigment are listed in Tables S3 and S4. Only commercially available applications were considered, based on market reports. ${ }^{3,9}$ Product allocations were assumed to be constant over time as no information on historic product distributions was available.

First, the nanoproducts and conventional pigment products were distinguished based on particle size. Nanoproducts were defined as products containing nanomaterials with $50 \%$ or more of their primary particles ranging from $1-100 \mathrm{~nm}$ in the number distribution. ${ }^{10}$ Among the nanoproducts, photocatalytic activity was the functionality used to allocate crystalline structure (anatase or rutile) to specific product categories. Nano-anatase is primarily used in applications requiring photocatalytic properties, whereas nano-rutile is employed as a UV light stabilizer. $\mathrm{Nano}^{-\mathrm{TiO}_{2}}$ used in sunscreens was classified in the separate category of nanocomposites as they are observed to be composed of a nano$\mathrm{TiO}_{2}$ rutile core coated with surface layers. When coated like this, nanocomposite-based structures remain intact as submicronic aggregates after aging under environmental conditions. $^{52}$

Except for $\mathrm{TiO}_{2}$ pigment in the anatase form, used as a food additive, all other commercially available $\mathrm{TiO}_{2}$ pigments are surface-treated using a variety of oxide and oxyhydrate coatings of aluminum and silicium. ${ }^{4,6,53}$ In some applications, silicone or organic coatings may be applied as a second coating layer to change the surface from hydrophilic to hydrophobic.' The weathering of the $\mathrm{TiO}_{2}$ pigments used in paints and coatings may lead to pigment chalking, an effect that is more likely with anatase pigments. ${ }^{4}$ Anatase pigments are therefore more commonly used in indoor paints and coatings, whereas rutile $\mathrm{TiO}_{2}$ pigments are mostly found in outdoor applications. Decor paper accounts for $82 \%$ of nano- $\mathrm{TiO}_{2}$ consumption in the paper industry, and rutile $\mathrm{TiO}_{2}$ pigments are ideal for this application requiring high opacity and color stability. Other writing and printing papers mostly contain anatase pigments. ${ }^{54}$

Size Distribution. Information on particle sizes was collected for each form of $\mathrm{TiO}_{2}$. We built probability distributions based on the mean values and size ranges provided by manufacturers, published papers, or market reports (see the Supporting Information, Section 4). The resulting distribution types include truncated normal distributions, triangular distributions, and Gaussian distributions. We mostly focused on primary particle sizes as measured using transmission electron microscopy and scanning electron microscopy. Hydrodynamic particle sizes determined using dynamic light scattering as well as nanoparticle tracking analysis were excluded. As listed in Tables S5-S7, nine data points found for nano-anatase helped to build the size distribution. Only one manufacturing source was identified for rutile ENMs. Twelve data points were collected for anatase pigments, six for rutile pigments, and fourteen for nanocomposites. Subsequently, we ran two sub-models for each form of $\mathrm{TiO}_{2}$ - one for sizes smaller than $100 \mathrm{~nm}$ and the other for sizes larger than $100 \mathrm{~nm}$-by using the corresponding mass concentrations determined from the size distributions. The only difference in the transfer coefficients between those two sub-modes was size-specific WWTP efficiency, as explained in the following section.

WWTP Efficiency. Of all the technical compartments, WWTPs' primary processes exhibit size-specific treatment efficiency. The historical evolution of different treatment steps was included in a previous dynamic model and was reproduced here. ${ }^{49}$ We considered that different particle size ranges would be removed with different efficiencies. The WWTP removal efficiencies given for $\mathrm{TiO}_{2}$ in different studies may refer to the removal of total $\mathrm{TiO}_{2}, \mathrm{TiO}_{2}$ ENMs, or filtered $\mathrm{TiO}_{2}$ particles within a certain size range. We critically examined the measurement methods in those studies and distinguished the removal efficiencies for nanosized $\mathrm{TiO}_{2}(<100 \mathrm{~nm})$ and $\mathrm{TiO}_{2}$ 

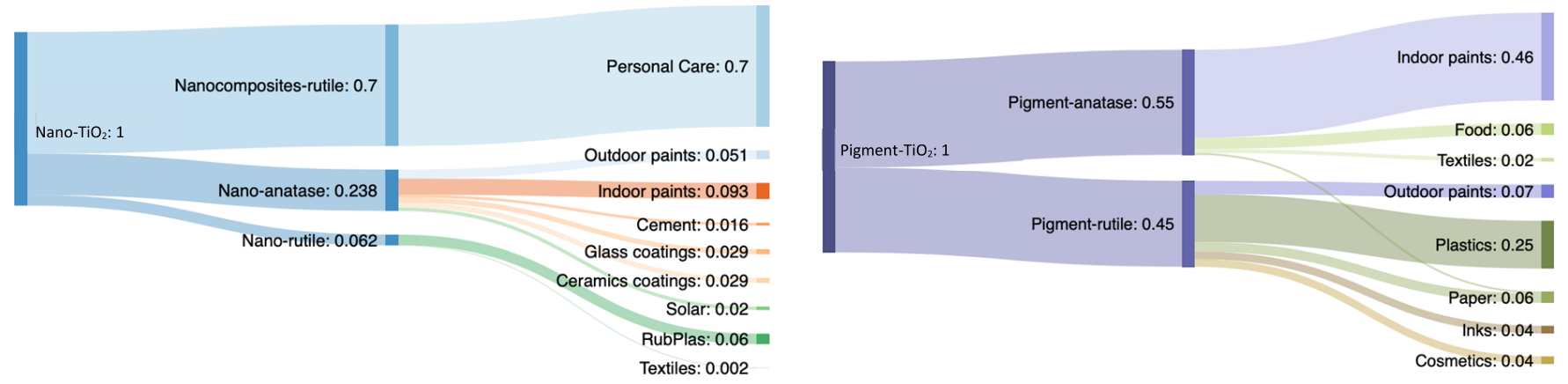

Figure 1. Sankey charts showing the relative allocations of nano- $\mathrm{TiO}_{2}$ (left) and $\mathrm{TiO}_{2}$ pigments (right) to the various product categories using the decision outlined in Figure S2.

\section{(a) nano- $\mathrm{TiO}_{2}$ production evolution}

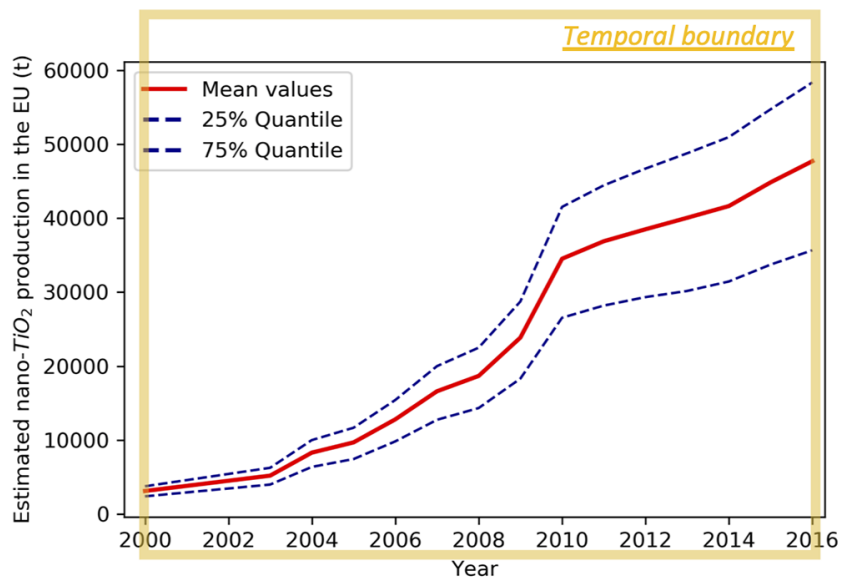

(c) nano- $\mathrm{TiO}_{2}$ production distribution in 2016

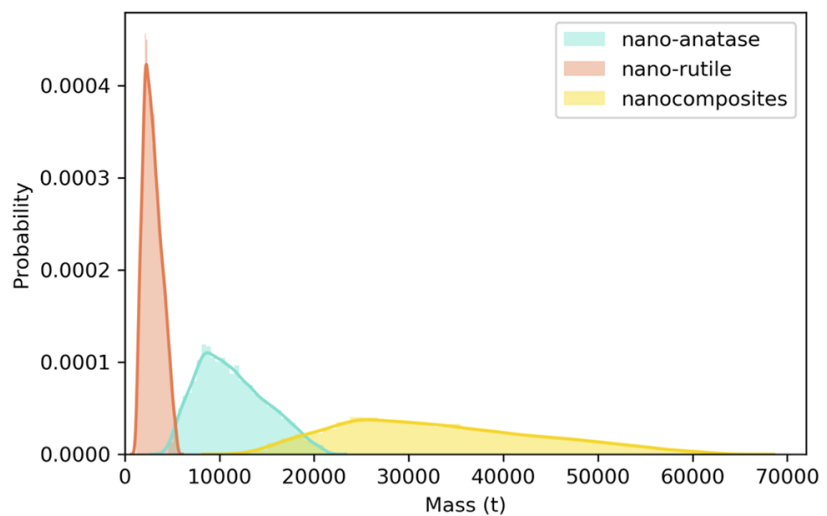

(b) pigment- $\mathrm{TiO}_{2}$ production evolution

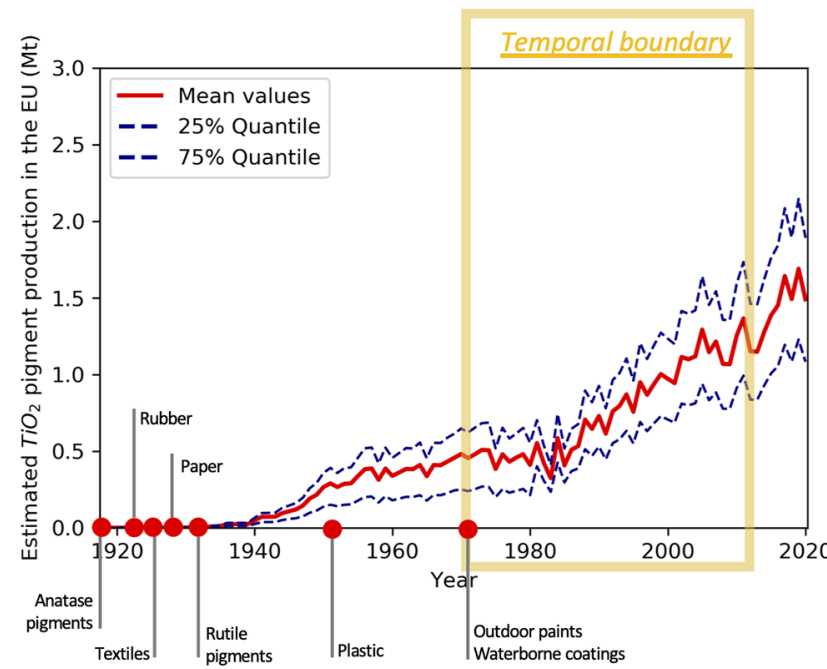

(d) pigment- $\mathrm{TiO}_{2}$ production distribution in 2016

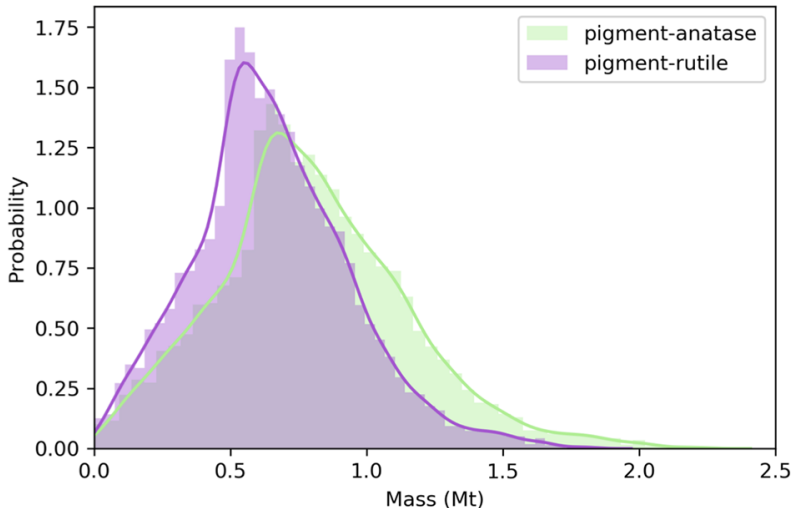

Figure 2. Modeled development of (a) nano- $\mathrm{TiO}_{2}$ (in t) from 2000-2016 and (b) $\mathrm{TiO}_{2}$ pigments (in Mt) from 1918-2020 in Europe. These graphs show mean probability distributions and the 25 th and 75th percentiles. Red dots in (b) indicate the years when $\mathrm{TiO}_{2}$ pigments started to be used in different applications. The nano- $\mathrm{TiO}_{2}$ model's temporal boundary starts in 2000 , when nanoproducts were first commercialized. $\mathrm{The}^{\mathrm{TiO}} \mathrm{O}_{2}$ pigment model's temporal boundary starts in 1970 when all the major applications, including paints, plastic, and paper had come to market. Graphs (c) and (d) show the 2016 probability distributions of the production volumes of nano- $\mathrm{TiO}_{2}$ and $\mathrm{TiO}_{2}$ pigments, respectively.

larger than $100 \mathrm{~nm}$, respectively. The following three criteria were applied to screen for published papers on WWTPs' removal efficiencies for nano- $\mathrm{TiO}_{2}<100 \mathrm{~nm}$ : (i) no sedimentation or filtration processes were conducted before sampling analysis; (ii) experiments were conducted using environmentally relevant concentrations of ENMs $(<10 \mathrm{mg} /$ L); and (iii) drinking water treatment processes were not considered. Unfortunately, no pilot-scale or full-scale data from
WWTPs met these criteria, and only data from laboratory-scale tests were found. For $\mathrm{TiO}_{2}$ particles larger than $100 \mathrm{~nm}$, we estimated the WWTP removal efficiencies according to studies reporting total $\mathrm{TiO}_{2}$ concentrations. The WWTP removal efficiencies for $\mathrm{TiO}_{2}$ particles larger than $100 \mathrm{~nm}$ are higher (10-99\%) than those for $\mathrm{TiO}_{2}$ particles smaller than $100 \mathrm{~nm}$ (46-100\%). The specific efficiency depends also on the 
(a) nano-anatase

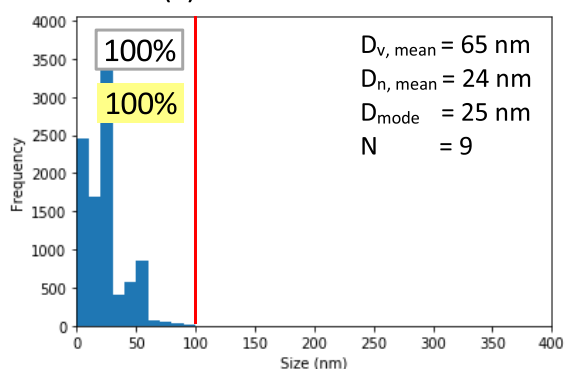

(c) pigment-anatase

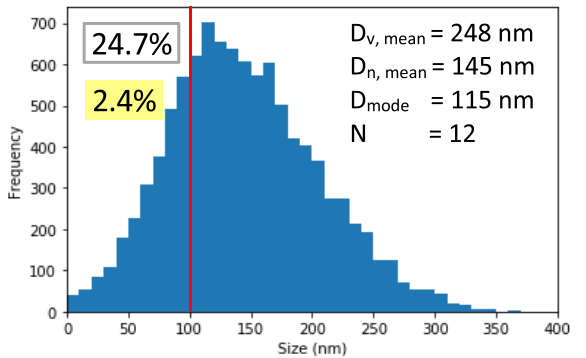

(b) nano-rutile

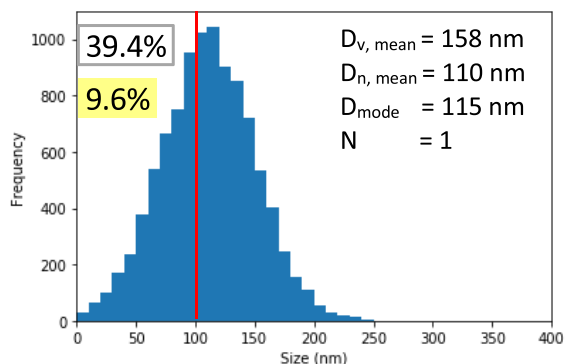

(d) pigment-rutile

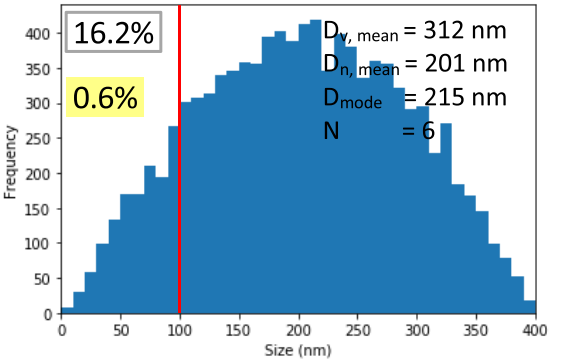

(e) nanocomposites

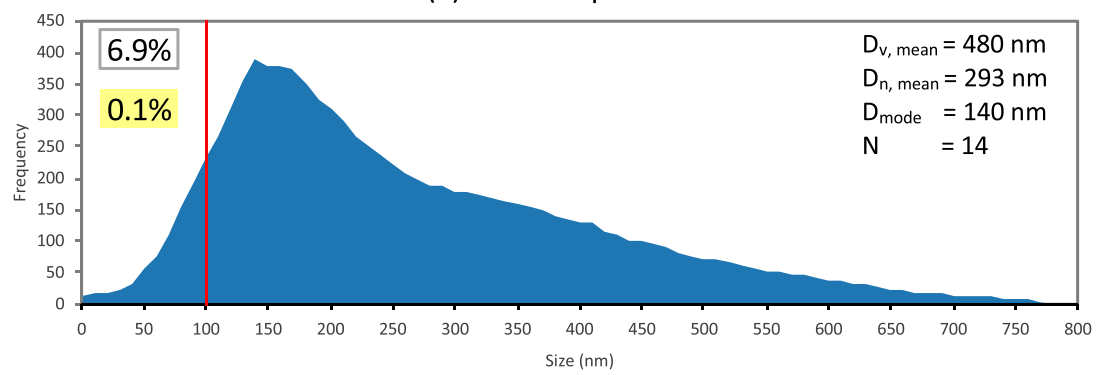

Number concentration $<100 \mathrm{~nm}$

Mass concentration $<100 \mathrm{~nm}$

Figure 3. Estimated number-based particle size distribution of $\mathrm{TiO}_{2}$ in different forms. (a) nano-anatase, (b) nano-rutile, (c) anatase pigment, (d) rutile pigment, and (e) nanocomposites. The red lines mark the upper limit of the nanorange. The number and mass concentration of particles smaller than $100 \mathrm{~nm}$ are given in the top left corner of each subplot. $D_{\mathrm{v}, \text { mean }}$ : volume average size; $D_{\mathrm{n} \text {, mean }}:$ number average size; $D_{\text {mode }}$ : mode size; $N$ : number of data points collected from the literature. The raw data used to derive these distributions are given in Tables S4-S6.

treatment level applied (primary, secondary, and tertiary). All the data and references used are listed in Table S14.

\section{RESULTS}

Product Allocation. The total productions of nano- $\mathrm{TiO}_{2}$ and $\mathrm{TiO}_{2}$ pigments were allocated to different product categories, as shown in Figure 1. The biggest nano- $\mathrm{TiO}_{2}$ use was in personal care products with a sun-blocking function, accounting for $70 \%$ of production. These particles are used in the form of nanocomposites. Nano-anatase and nano-rutile represent 24 and $6 \%$ of total $\mathrm{TiO}_{2}$ ENM production, respectively. The allocation of $\mathrm{TiO}_{2}$ pigment products was relatively evenly distributed between the crystalline forms, with $55 \%$ anatase and $45 \%$ rutile. Their main applications were indoor paints for anatase (46\%) and plastics for rutile (25\%). The E171 food additive accounts for $6 \%$ of $\mathrm{TiO}_{2}$ pigment use.

Production Volume. The temporal evolution of nano$\mathrm{TiO}_{2}$ production volumes was modeled from 2000-2016 (Figure 2a) and for $\mathrm{TiO}_{2}$ pigments from 1918-2016 (Figure $2 \mathrm{~b})$. The red points in Figure $2 \mathrm{~b}$ highlight several critical industrial milestones in the history of $\mathrm{TiO}_{2}$ pigment production (see the Supporting Information, Section 2.2). By 1970, all the current major applications for $\mathrm{TiO}_{2}$ had come to market on an industrial scale; therefore, the temporal modeling boundary was set to begin in 1970 . Due to the scarcity of information on the evolution of product shares, no product allocation dynamics were modeled.

$\mathrm{TiO}_{2}$ ENMs have been commercialized worldwide since 2000. In 2016, the European nano- $\mathrm{TiO}_{2}$ production $(47,000$ tons) was estimated to be around $3 \%$ of its $\mathrm{TiO}_{2}$ pigment production $(1,418,000$ tons). The inherent uncertainty of all the input parameters was addressed using probabilistic methods. This means that all the data sources for each parameter were combined into an appropriate probability density distribution by considering the data's reliability (see the Supporting Information, Section 1.3). Figure 2c,d shows the probability density distributions of nano- $\mathrm{TiO}_{2}$ and $\mathrm{TiO}_{2}$ pigment production in 2016. Nano-rutile was the least produced, with a mode value of 2,900 tons. Nanocomposites were the most produced and most widely distributed, with a mode value of approximately 25,000 tons. The distribution of $\mathrm{TiO}_{2}$ pigments between anatase and rutile showed similar mode values of 680,000 and 550,000 tons, respectively.

Size Distribution. The modeled size distributions for the five forms of $\mathrm{TiO}_{2}$ are depicted in Figure 3. Nano-anatase is the only form that consists of $100 \%$ nanosized particles. Only one data source was found for the nano-rutile used in plastics 
(a) Production

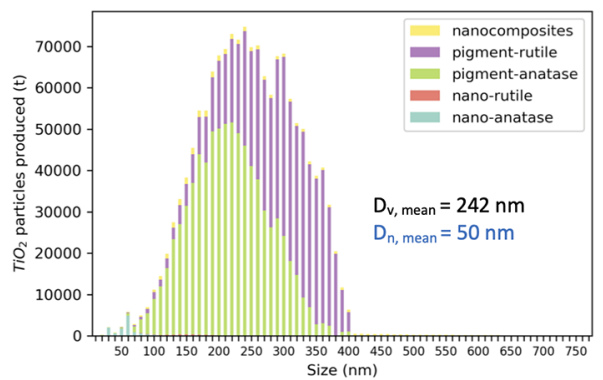

(d) Natural \& urban soil

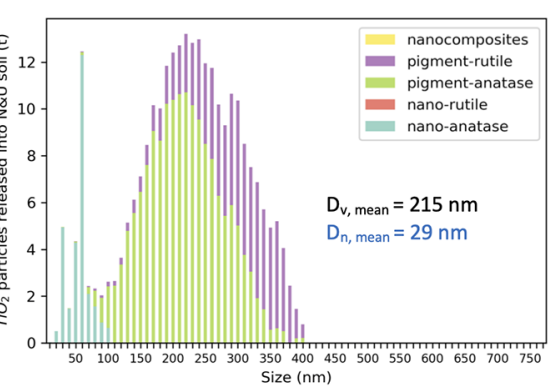

(b) Air

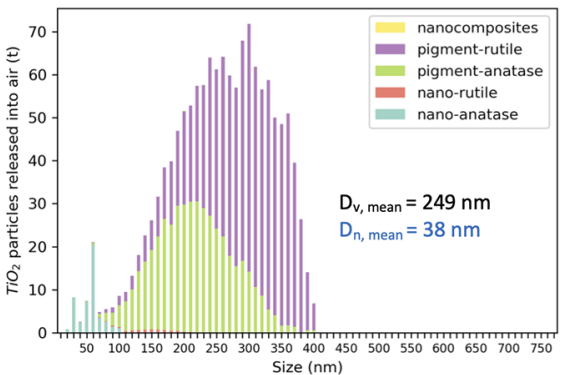

(e) Sludge-treated soil

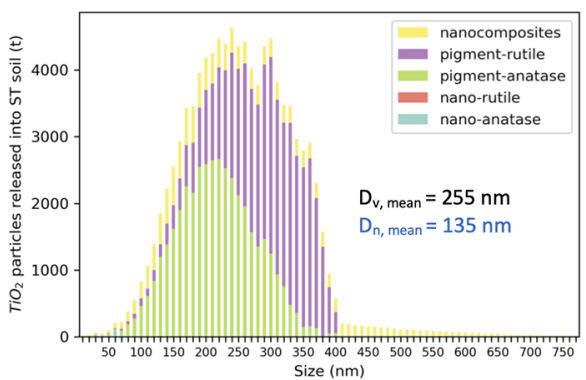

(c) Surface water

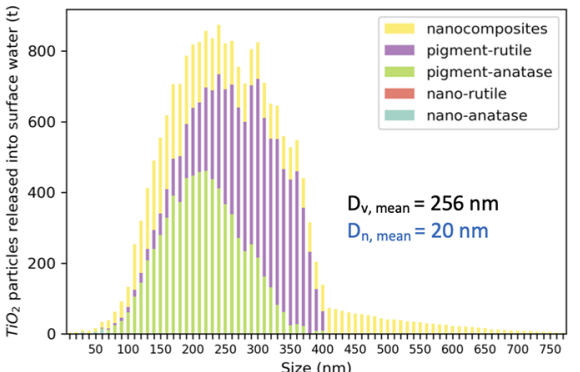

(f) Subsurface soil

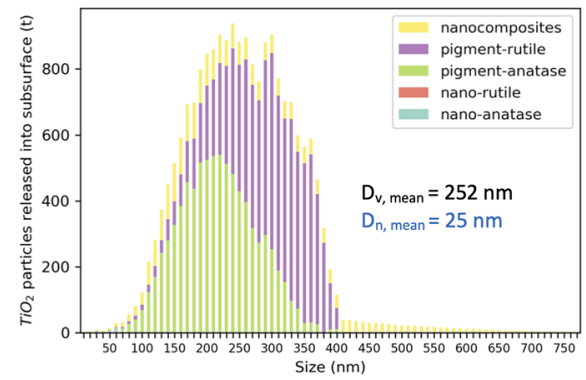

Figure 4. Mass-based size distribution of pristine $\mathrm{TiO}_{2}$ particles produced and released into five environmental compartments in 2016 . Volume average size $\left(D_{\mathrm{v}, \text { mean }}\right)$ and number average size $\left(D_{\mathrm{n} \text {,mean }}\right)$ are labeled in each subplot. Number-based size distributions can be found in Figure S11. The enlarged size distribution of nanosized particles $(<100 \mathrm{~nm})$ can be found in Figure S10.

and textiles (referring to DuPont's Light Stabilizer 210 product). ${ }^{55}$ Based on the truncated normal distribution derived from the available information, we estimate that nano-rutile is made up of $39 \%$ nanosized particles by number and that more than $90 \mathrm{wt} \%$ is made up of particles larger than $100 \mathrm{~nm}$. This material's surface is coated with aluminum hydroxide, silane, siloxane, or amorphous silica to prevent the interaction of its excited electrons with the surrounding matrix (plastics) and to improve its compatibility with its end use (textiles). ${ }^{5}$

Rutile pigments have a broader size distribution (0-400 $\mathrm{nm})$ than anatase pigments $(0-360 \mathrm{~nm})$. For rutile, $1.6 \%$ of the particle mass measures below $100 \mathrm{~nm}$, and for anatase, this is $2.4 \%$. Of the five forms of $\mathrm{TiO}_{2}$ considered, nanocomposites have the broadest size range $(0-800 \mathrm{~nm})$ and the lowest percentage of nanosized particles $(0.1$ wt \%). By combining Figure 3's size information with Figure 1's product allocation information, it can be derived that approximately $75 \%$ of the $\mathrm{TiO}_{2}$ ENMs used in nanoproducts are not in fact present in the form of single nanoparticles but rather as nanocomposites with aggregate particle sizes larger than $100 \mathrm{~nm}$. For pigments, around $1.6 \mathrm{wt} \%$ of the particles used in products measure below $100 \mathrm{~nm}$.

Figure S9 in the Supporting Information shows the detailed mass flow diagrams of the five forms of $\mathrm{TiO}_{2}$ from production to end-of-life for Europe in 2016. The accumulated mass in stocks and sink compartments was derived from the dynamic modeling. The mass flows are split into pristine particles smaller than $100 \mathrm{~nm}$, pristine particles larger than $100 \mathrm{~nm}$, matrix-embedded $\mathrm{TiO}_{2}$, transformed $\mathrm{TiO}_{2}$, and productembedded $\mathrm{TiO}_{2}$. By combining the particle size distributions of the five forms considered in Figure 3 and the masses of the flows shown in Figure S9, we can calculate the overall size distribution of $\mathrm{TiO}_{2}$. As demonstrated in Figure 4, the average size of $\mathrm{TiO}_{2}$ particles produced and released is predicted to be around $250 \mathrm{~nm}$. $\mathrm{TiO}_{2}$ pigments contributed most of the release. $\mathrm{TiO}_{2}$ particles released into sludge have a much higher number average size $\left(D_{\mathrm{n} \text {,mean }}\right.$ of $\left.135 \mathrm{~nm}\right)$ than those released into surface water $(20 \mathrm{~nm})$ and the subsurface $(25 \mathrm{~nm})$. The larger size in sludge is caused by wastewater treatments greater removal efficiency for larger particles, as listed in Table S14. Accordingly, a higher ratio of larger-sized particles is captured in the sludge rather than being released into surface water. Compared with the particle size distribution after production $\left(D_{\mathrm{n}, \text { mean }}=50 \mathrm{~nm}\right)$, particles released into air and natural and urban soil compartments have much smaller number average sizes of 38 and $29 \mathrm{~nm}$, respectively. Anatase $\mathrm{TiO}_{2}$ nanoparticles dominate the particles below $100 \mathrm{~nm}$ released into those two compartments.

Mass Flows of Nanosized $\mathrm{TiO}_{2}$. Figure 5 shows the material flows of the nanosized fraction of nano- $\mathrm{TiO}_{2}$ particles and $\mathrm{TiO}_{2}$ pigment and the shares of the five forms (nanoanatase, nano-rutile, anatase pigment, rutile pigment, and nanocomposites) in each compartment in Europe in 2016. The contribution of $\mathrm{TiO}_{2}$ pigments to the nanosized $\mathrm{TiO}_{2}$ fraction is significant, ranging from 13 to $92 \%$ throughout the whole life cycle. Already during production, the contribution of nanosized $\mathrm{TiO}_{2}$ from bulk conventional pigments (62\%) is larger than the one from $\mathrm{TiO}_{2}$ manufactured intentionally at the nanoscale (38\%). Anatase pigment contributes nearly half of the nanosized particles. The second significant contributor is nano-anatase. Landfill and sludge-treated soil are the environmental compartments accumulating the largest amounts of nanosized $\mathrm{TiO}_{2}$ particles, with masses of 80,000 and 40,760 tons, respectively. Nano-anatase forms the highest proportion in the air and natural and urban soil compartments. This might be related to the small size of particles released from paints and coatings during weathering processes. Because they are mainly used in plastics, rutile pigments mostly remain in the in-use stock or end up exported or reprocessed to reuse. Nanocomposites and anatase pigment dominate the release of nanosized $\mathrm{TiO}_{2}$ particles to wastewater-related compartments, 


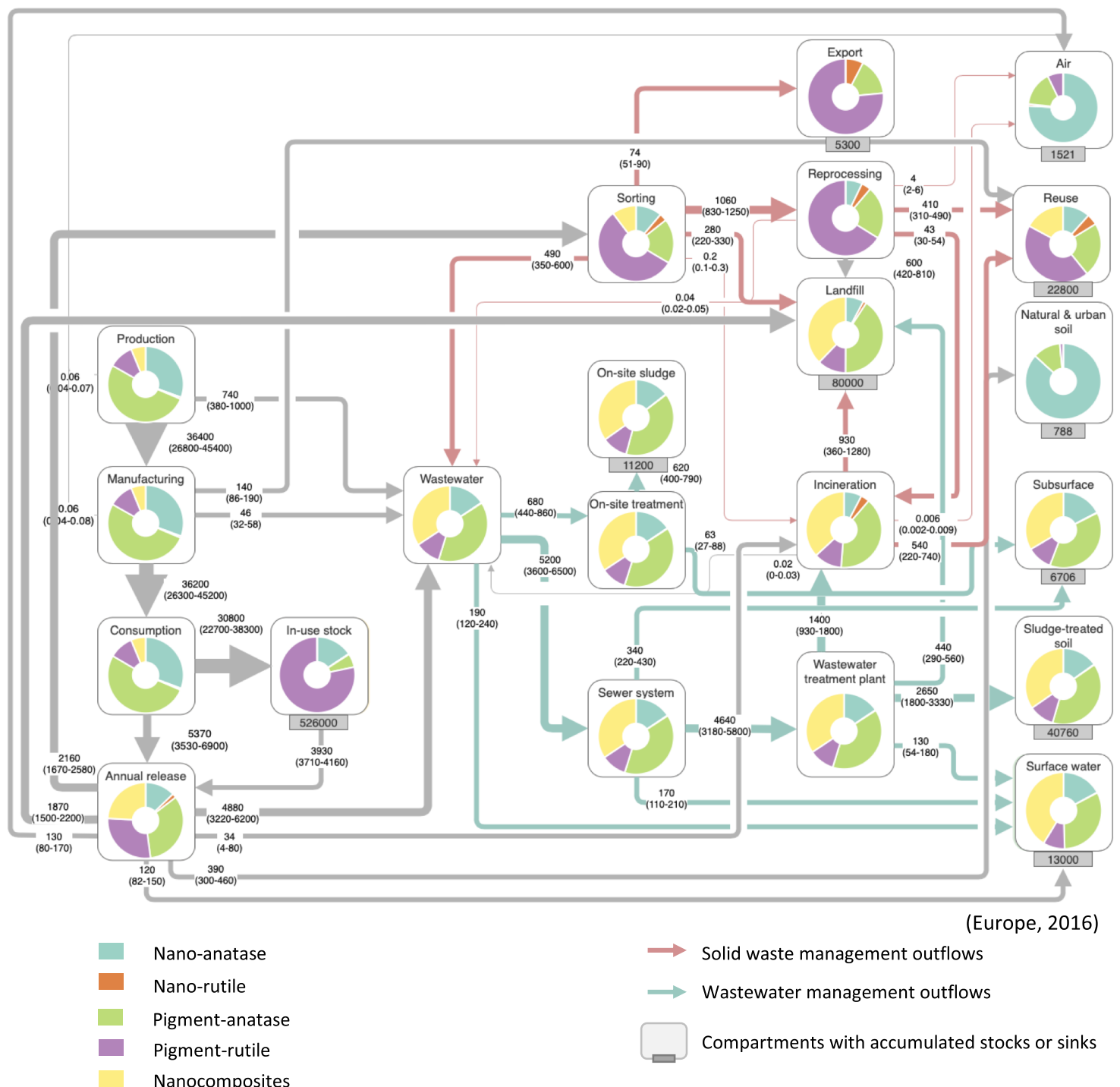

Figure 5. Contribution of five different $\mathrm{TiO}_{2}$ forms to the relative distribution of the nanosized $\mathrm{TiO}_{2}$ fraction $(<100 \mathrm{~nm})$ in different environmental and technical compartments in Europe in 2016. Flow values are the rounded means of the probability distributions in tons. The 25th and 75th percentiles of the probability distributions are shown in brackets. Ring plots show the proportion of different forms in each compartment. Flow widths are proportional to flow sizes.

mainly through the contribution of sunscreen and food products.

Temporal Evolution. Figure 6 shows the temporal evolution of the nanosized $\mathrm{TiO}_{2}$ fraction originating from both nano- $\mathrm{TiO}_{2}$ and $\mathrm{TiO}_{2}$ pigment from 1970-2016. We estimated that 22,400 tons of nanosized particles were released into the environment up until 1999. After ENMs were introduced onto the market in 2000, the production of nanosized $\mathrm{TiO}_{2}$ particles increased steadily from 15,000 to 35,000 tons in 2016. The major change in environmental release was that nano-anatase particles started to dominate the release of nanosized particles into air and natural and urban soils, with exponential growth after 2000. In 2016, more than $70 \%$ of nanosized $\mathrm{TiO}_{2}$ release came from nano-anatase. The changes in the environmental compartments linked to wastewater, including surface water, sludge-treated soil, and subsurface soil, were relatively gradual. In 2016, up to $50 \%$ of the release still came from $\mathrm{TiO}_{2}$ pigments, with the rest mostly from nanocomposites and nano-anatase. The increase in nanocomposites in surface water is mainly due to the increasing use of nano- $\mathrm{TiO}_{2}$ in sunscreens.

\section{DISCUSSION}

To the best of our knowledge, the present study is the first to evaluate the size distribution of a particulate material from production to use and to release into final technical and environmental sinks. We investigated the size distribution of titanium dioxide $\left(\mathrm{TiO}_{2}\right)$ in different product categories and distinguished between nano- $\mathrm{TiO}_{2}$ and $\mathrm{TiO}_{2}$ pigments, between the anatase and rutile crystalline forms, and between coated and uncoated particles. Furthermore, as opposed to previous studies, ${ }^{47,49}$ nano- $\mathrm{TiO}_{2}$ and $\mathrm{TiO}_{2}$ pigment production volumes and product allocations were updated based on real market data.

The most striking data to emerge from this study was that nanoscale $\mathrm{TiO}_{2}$ was produced well before $\mathrm{TiO}_{2}$ engineered nanomaterials (ENMs) came onto the market in 2000, with 22,400 tons of nanosized $\mathrm{TiO}_{2}$ being released into the environment up until 1999. Even in 2016, 50\% of the 
(a) Production

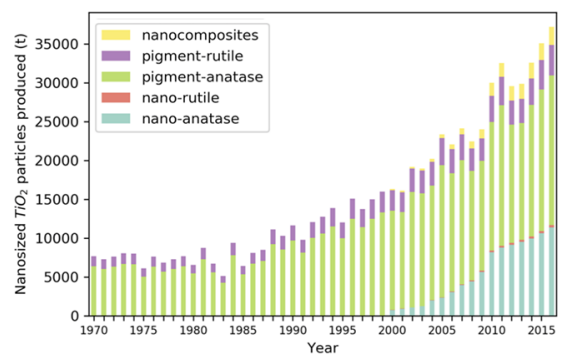

(d) Natural \& urban soil

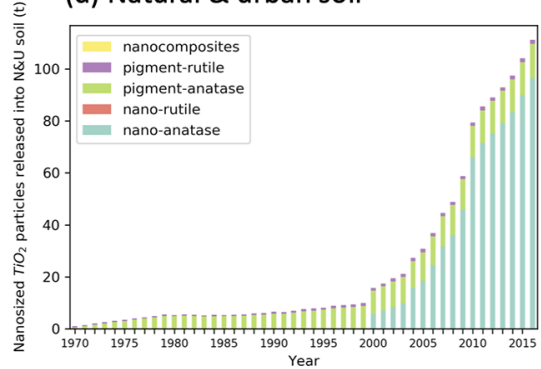

(b) Air

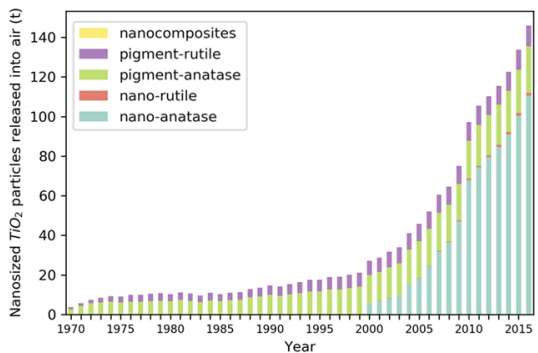

(e) Sludge-treated soil

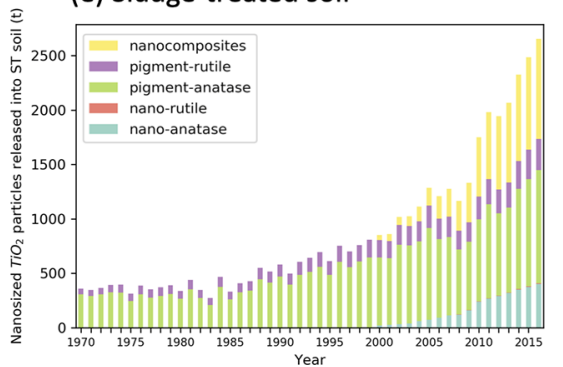

(c) Surface water

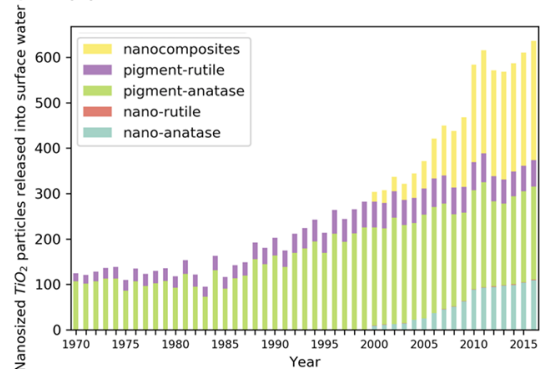

(f) Subsurface soil

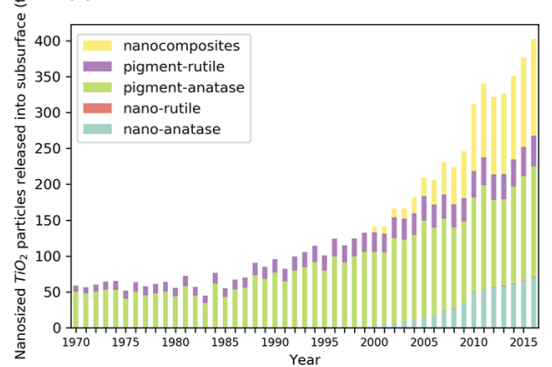

Figure 6. Evolution of the mass of the five different forms of pristine nanosized $\mathrm{TiO}_{2}(<100 \mathrm{~nm})$ originating from nano- $\mathrm{TiO}_{2}$ and $\mathrm{TiO}_{2}$ pigments at production and in environmental compartments from 1970-2016. Nano-anatase, nano-rutile, and nanocomposites were modeled as being first produced in 2000 .

nanosized $\mathrm{TiO}_{2}$ released into wastewater-related compartments was contributed by $\mathrm{TiO}_{2}$ pigment products. This finding highlights the importance of including the conventional $\mathrm{TiO}_{2}$ pigments in any analysis of nanosized $\mathrm{TiO}_{2}$ particles. The results further indicated that different crystalline forms of $\mathrm{TiO}_{2}$ showed considerable variability in their environmental release profiles into different compartments. This was in line with a previous modeling analysis concluding that anatase exhibits more release to the air and less release to wastewater-related compartments than rutile does. ${ }^{44,45}$

Our additional insights into crystalline forms and coatings prepare the way for more advanced hazard assessments of nanomaterials in ecological systems. The first environmental risk assessment of nano- $\mathrm{TiO}_{2}$ was based on a generic nano$\mathrm{TiO}_{2}$, lumping together all forms of $\mathrm{TiO}_{2}$ for both the exposure and hazard assessments. ${ }^{56}$ Risk was evaluated by deriving a predicted no-effect concentration (PNEC) from a species sensitivity distribution containing ecotoxicological data for all types of nano- $\mathrm{TiO}_{2}$. Wigger and Nowack showed that distinct exposure and hazard assessments for anatase and rutile were possible for nano- $\mathrm{TiO}_{2}$ and that separate, full-risk assessments could be performed. ${ }^{45}$ These authors obtained variations in the predicted environmental concentrations for anatase and rutile from a factor of 2 to 13 . The mean PNEC of nano-anatase ( 38 $\mu \mathrm{g} / \mathrm{L})$ was found to be similar to that of rutile $(33 \mu \mathrm{g} / \mathrm{L})$. Although these different nanoforms showed similar PNECs, nano-rutile had a risk characterization ratio 10 times higher than anatase because of its higher predicted environmental concentration. This preliminary work nevertheless showed that it was possible to conduct form-specific exposure and hazard assessments instead of using a generic $\mathrm{TiO}_{2}$ model. Although Wigger and Nowack ${ }^{45}$ assessed the toxicity of $\mathrm{TiO}_{2}$ ENMs used in sunscreen products by using data on pristine rutile nanoparticles, nano- $\mathrm{TiO}_{2} \mathrm{UV}$ filters are in fact usually coated rutile nanoparticles in the form of nanocomposites. ${ }^{13}$ The fates and toxicities of these nanocomposites in the environment are entirely different from that of uncoated particles. ${ }^{13}$ For example, the surface layers of nano- $\mathrm{TiO}_{2} \mathrm{UV}$ filters have the potential to favor biocompatibility and block any chemical reactions with the $\mathrm{TiO}_{2}$ core. ${ }^{57}$ As pointed out by Pan et al., ${ }^{58}$ $\mathrm{TiO}_{2}$ nanoparticles can easily penetrate cell membranes and impair cell proliferation rates, whereas coated particles could not penetrate cells, thus allowing normal cell function. They found that after incubation with coated rutile nanoparticles, there were $6 \%$ fewer cells than in the control sample, whereas cells incubated with uncoated rutile particles were $70 \%$ fewer. The ROS generation of the coated $\mathrm{TiO}_{2}$-based nanomaterials used in cosmetics was also compared to that of uncoated nano$\mathrm{TiO}_{2}{ }^{52}$ A total of $25 \mathrm{mg} / \mathrm{L}$ of uncoated particles generated superoxide, whereas $130 \mathrm{mg} / \mathrm{L}$ of coated nano- $\mathrm{TiO}_{2}$ particles generated no detectable ROS. ${ }^{52}$ To date, there have been no ecotoxicological studies involving unaltered nanocomposites, but several studies involving nanocomposites aged under environmental conditions have been published. ${ }^{59-62}$ These studies supported hypotheses about the very low toxicity of these coated materials. Because we predict that more than $50 \%$ of the nanosized $\mathrm{TiO}_{2}$ particles reaching surface water are actually coated (coating information is shown in Figure S2), it is of utmost importance that the hazard assessments of nano$\mathrm{TiO}_{2}$ be based on the forms actually present in particular environmental compartments.

A complete risk assessment of $\mathrm{TiO}_{2}$ in the environment should also consider the presence of $\mathrm{TiO}_{2}$ pigments. A recent study compared the toxicity of nano- $\mathrm{TiO}_{2}$ (P25), food-grade $\mathrm{TiO}_{2}$ (E171), and bulk $\mathrm{TiO}_{2}$, with results suggesting that nano$\mathrm{TiO}_{2}$ exhibited greater phototoxicity than the other two forms. ${ }^{63}$ All three $\mathrm{TiO}_{2}$ materials induced chronic toxicity effects, including shortened lifespan and reduced reproduction. In earlier in vitro studies, E171 was found to induce oxidative stress and genotoxicity. ${ }^{64,65}$ The initial primary particle size was identified as a critical factor in determining the toxicity of $\mathrm{TiO}_{2}{ }^{22}$ Smaller sized particles $(55 \mathrm{~nm})$ showed a $90 \%$ lower 
Daphnia $\mathrm{EC}_{50}$ value than larger particles $(140 \mathrm{~nm}) .^{22}$ In another study, the generation of ROS was proven to increase as the primary particle size decreased. ${ }^{66}$

The present study's quantitative data on the particle size distribution of $\mathrm{TiO}_{2}$ particles released into the environment could be used as input for such environmental multimedia fate models as SimpleBox4nano, ${ }^{68}$ MendNano, ${ }^{68}$ and nanoFate. ${ }^{69}$ ENM fate processes such as rain scavenging, dissolution rate, dry deposition, sedimentation, aggregation, and attachment efficiency are all governed by particle size. ${ }^{67,70}$ To date, these fate models have used number-based size distributions, ${ }^{68}$ average primary diameter, or the average aggregate radius in freshwater ${ }^{69}$ as their input. Yet, these published fate models did not specify the data sources used to obtain their size information. By using the present study's size distribution data on the $\mathrm{TiO}_{2}$-particles released into the environment, fate models could improve their estimations of this crucial parameter.

The size distributions predicted by our model can be compared to analytical studies, which looked at the sizes and forms of $\mathrm{TiO}_{2}$ in wastewater and environmental samples. As observed by Lange et al., the size distributions, which we modeled, pointed to a shift toward larger particles in sludge $\left(D_{\mathrm{n}, \text { mean }}=135 \mathrm{~nm}\right)$ and the release of smaller particles into surface waters $\left(D_{\mathrm{n} \text {,mean }}=20 \mathrm{~nm}\right)$ during wastewater treatment. ${ }^{71}$ Baalousha et al. analyzed the size distribution of engineered $\mathrm{TiO}_{2}$ collected from soils in stormwater green infrastructure. $^{35}$ They described a mode value in the size distribution of engineered $\mathrm{TiO}_{2}$ of around $50 \mathrm{~nm}$, which agreed well with our findings about nanosized $\mathrm{TiO}_{2}$ particles in natural and urban soils. Nevertheless, they acknowledged that they were unable to extract all the $\mathrm{TiO}_{2}$ particles from the hetero-aggregates in their samples. $\mathrm{TiO}_{2}$ particles were also measured in recreational waters where sunscreen use is intense. $^{31,72,73}$ Only a fraction of the particles showed morphological similarities and a similar size distribution to particles from sunscreen products. However, Ti-containing particles released into water from other applications, such as food or paints, were the focus of these studies targeting situations involving high sunscreen use.

Our work provides a starting point from which to integrate particle size, crystalline form, and type of coating into MFAs of $\mathrm{TiO}_{2}$, and the model should be extended to other ENMs too. The main challenge of adapting the current model to other types of ENM would be obtaining enough information on the particle size distribution of the materials used in products actually on the market. Given that our findings were based on a limited number of size distributions, the results from this first analysis should be treated with caution. The uncertainties of the size distributions in different environmental compartments could be reduced by further studies on the sizing and surface properties of $\mathrm{TiO}_{2}$ particles that are actually used in products and represent the material on the market. The present study has only investigated the size distribution of the pristine materials. Consequently, no distinction could be made among single, homo-agglomerated, and hetero-aggregated particles. More research is required on the particle structure of nanorutile as used as a UV stabilizer product in plastics and textiles. Whether these materials are manufactured and coated in the same way as the nanocomposites used in sunscreens also needs to be answered. Further improvements to modeling methods could include considering seasonal variations in sunscreen usage, which is especially relevant to the contamination of recreational surface waters in summer. ${ }^{74}$ To build a better connection with fate models, particle shape and surface charge could be potential additional characteristics to be included in the next generation of nanospecific MFA models; however, this requires again knowledge on these characteristics in the materials used in actual products on the market.

\section{ASSOCIATED CONTENT}

\section{Supporting Information}

The Supporting Information is available free of charge at https://pubs.acs.org/doi/10.1021/acs.est.0c07446.

Details on the modeling method; input data for production volume, product distribution, particle size, release from products, and release during wastewater treatment; transfer coefficients during use and EoL; and additional results (PDF)

\section{AUTHOR INFORMATION}

\section{Corresponding Author}

Bernd Nowack - Empa, Swiss Federal Laboratories for Materials Science and Technologies, 9014 St. Gallen, Switzerland; 이이.org/0000-0002-5676-112X; Email: nowack@empa.ch

\section{Author}

Yuanfang Zheng - Empa, Swiss Federal Laboratories for Materials Science and Technologies, 9014 St. Gallen, Switzerland; o orcid.org/0000-0002-6715-0156

Complete contact information is available at: https://pubs.acs.org/10.1021/acs.est.0c07446

\section{Notes}

The authors declare no competing financial interest. Model availability: The codes, input files, and raw results are available for download at Zenodo: DOI: 10.5281/zenodo. 4422041 .

\section{ACKNOWLEDGMENTS}

This work was supported by the European Union's Horizon 2020 research and innovation program under grant agreement 814426 (NanoInformaTIX).

\section{REFERENCES}

(1) Dictionary of building preservation. Choice Reviews Online. 1997, 34 (07), 34-3628, DOI: 10.5860/choice.34-3628.

(2) Braun, J. H.; Baidins, A.; Marganski, R. E. $\mathrm{TiO}_{2}$ pigment technology: a review. Prog. Org. Coat. 1992, 20, 105-138.

(3) Future Markets Inc. The global market for Titanium Dioxide; 2017 [accessed 2020 Nov 8]. https://www.futuremarketsinc.com/theglobal-market-for-titanium-dioxide-to-2025/

(4) Auer, G., Griebler, W.-D., Jahn, B. White Pigments. In Industrial Inorganic Pigments; John Wiley \& Sons, Ltd: 2005, p. 51-97, DOI: $10.1002 / 3527603735 . c h 2$

(5) Varner, K. E.; Rindfusz, K.; Gaglione, A.; Viveiros, E. Nano Titanium Dioxide Environmental Matter: State of the Science Literature Review. U.S. Environmental Protection Agency; 2010. https://cfpub.epa. gov/si/si_public_record_report.cfm?Lab=NERL\&dirEntryId= 227225

(6) Veronovski, N. Titanium Dioxide - Material for a Sustainable Environment; 2018, DOI: 10.5772/intechopen.72945.

(7) IARC Working Group on the Evaluation of Carcinogenic. Titanium Dioxide. IARC Monogr. Eval. Carcinog. Risks Hum. 2013, $105,193-276$ 
(8) van Driel, B. A.; Kooyman, P. J.; van den Berg, K. J.; SchmidtOtt, A.; Dik, J. A quick assessment of the photocatalytic activity of $\mathrm{TiO}_{2}$ pigments - From lab to conservation studio! Microchem. J. 2016, 126, 162-171.

(9) Future Markets Inc. The global market for Titanium Dioxide Nanoparticles; 2017 [accessed 2020 Nov 8];(November). https:// www.futuremarketsinc.com/the-global-market-for-titanium-dioxidenanoparticles/

(10) European Commission Commission Recommendation of 18 October 2011 on the definition of nanomaterial Text with EEA relevance; 2011/696/EU. Luxembourg; 2011. p. 38-40.

(11) Godnjavec, J.; Znoj, B.; Venturini, P.; Žnidaršič, A. The application of rutile nano - Crystalline titanium dioxide as UV absorber. Informacije MIDEM. 2010, 40, 6-9.

(12) Wang, J.; Fan, Y. Lung injury induced by $\mathrm{TiO}_{2}$ nanoparticles depends on their structural features: Size, shape, crystal phases, and surface coating. Int. J. Mol. Sci. 2014, 15, 22258-22278.

(13) Labille, J.; Feng, J.; Botta, C.; Borschneck, D.; Sammut, M.; Cabie, M.; Auffan, M.; Rose, J.; Bottero, J. Y. Aging of $\mathrm{TiO}_{2}$ nanocomposites used in sunscreen. Dispersion and fate of the degradation products in aqueous environment. Environ. Pollut. 2010, 158, 3482-3489.

(14) Botta, C.; Labille, J.; Auffan, M.; Borschneck, D.; Miche, H.; Cabié, M.; Masion, A.; Rose, J.; Bottero, J. Y. TiO -based nanoparticles released in water from commercialized sunscreens in a life-cycle perspective: Structures and quantities. Environ. Pollut. 2011, 159, 1543-1550.

(15) Dudefoi, W.; Terrisse, H.; Richard-Plouet, M.; Gautron, E.; Popa, F.; Humbert, B.; Ropers, M.-H. Criteria to define a more relevant reference sample of titanium dioxide in the context of food: a multiscale approach. Food Addit. Contam., Part A 2017, 34, 653-613.

(16) Yang, Y.; Doudrick, K.; Bi, X.; Hristovski, K.; Herckes, P.; Westerhoff, P.; Kaegi, R. Characterization of food-grade titanium dioxide: The presence of nanosized particles. Environ. Sci. Technol. 2014, 48, 6391-6400.

(17) Weir, A.; Westerhoff, P.; Fabricius, L.; Hristovski, K.; Von Goetz, N. Titanium dioxide nanoparticles in food and personal care products. Environ. Sci. Technol. 2012, 46, 2242-2250.

(18) Peters, R. J. B.; Van Bemmel, G.; Herrera-Rivera, Z.; Helsper, H. P. F. G.; Marvin, H. J. P.; Weigel, S.; Tromp, P. C.; Oomen, A. G.; Rietveld, A. G.; Bouwmeester, H. Characterization of titanium dioxide nanoparticles in food products: Analytical methods to define nanoparticles. J. Agric. Food Chem. 2014, 62, 6285-6293.

(19) European Food Safety Authority. EFSA statement on the review of the risks related to the exposure to the food additive titanium dioxide (E 171) performed by the French Agency for Food, Environmental and Occupational Health and Safety (ANSES). EFSA J. 2019, 17, No. e05714.

(20) Candás-Zapico, S.; Kutscher, D. J.; Montes-Bayón, M.; Bettmer, J. Single particle analysis of $\mathrm{TiO}_{2}$ in candy products using triple quadrupole ICP-MS. Talanta 2018, 180, 309-315.

(21) Sun, T. Y.; Gottschalk, F.; Hungerbühler, K.; Nowack, B. Comprehensive probabilistic modelling of environmental emissions of engineered nanomaterials. Environ. Pollut. 2014, 185, 69-76.

(22) Seitz, F.; Rosenfeldt, R. R.; Schneider, S.; Schulz, R.; Bundschuh, M. Size-, surface- and crystalline structure compositionrelated effects of titanium dioxide nanoparticles during their aquatic life cycle. Sci. Total Environ. 2014, 493, 891-897.

(23) Capco, D. G., Chen, Y. Nanomaterial. Impacts on Cell Biology and Medicine; Springer: 2014, DOI: 10.1007/978-94-017-8739-0

(24) Jang, H. D.; Kim, S. K.; Kim, S. J. Effect of particle size and phase composition of titanium dioxide nanoparticles on the photocatalytic properties. J. Nanopart. Res. 2001, 3, 141-147.

(25) Sayes, C. M.; Wahi, R.; Kurian, P. A.; Liu, Y.; West, J. L.; Ausman, K. D.; Warheit, D. B.; Colvin, V. L. Correlating nanoscale titania structure with toxicity: A cytotoxicity and inflammatory response study with human dermal fibroblasts and human lung epithelial cells. Toxicol. Sci. 2006, 92, 174-185.
(26) Jiang, J.; Oberdörster, G.; Elder, A.; Gelein, R.; Mercer, P.; Biswas, P. Does nanoparticle activity depend upon size and crystal phase? Nanotoxicology 2008, 2, 33-42.

(27) El-Toni, A. M.; Yin, S.; Sato, T.; Ghannam, T.; Al-Hoshan, M.; Al-Salhi, M. Investigation of photocatalytic activity and UV-shielding properties for silica coated titania nanoparticles by solvothermal coating. J. Alloys Compd. 2010, 508, L1-L4.

(28) Lewicka, Z. A.; Yu, W. W.; Oliva, B. L.; Contreras, E. Q.; Colvin, V. L. Photochemical behavior of nanoscale $\mathrm{TiO}_{2}$ and $\mathrm{ZnO}$ sunscreen ingredients. J. Photochem. Photobiol., A 2013, 263, 24-33.

(29) Loosli, F.; Wang, J.; Rothenberg, S.; Bizimis, M.; Winkler, C.; Borovinskaya, O.; Flamigni, L.; Baalousha, M. Sewage spills are a major source of titanium dioxide engineered (nano)-particle release into the environment. Environ. Sci.: Nano 2019, 6, 763-777.

(30) von der Kammer, F.; Ferguson, P. L.; Holden, P. A.; Masion, A.; Rogers, K. R.; Klaine, S. J.; Koelmans, A. A.; Horne, N.; Unrine, J. $\mathrm{M}$. Analysis of engineered nanomaterials in complex matrices (environment and biota): General considerations and conceptual case studies. Environ. Toxicol. Chem. 2012, 31, 32-49.

(31) Gondikas, A. P.; Von Der Kammer, F.; Reed, R. B.; Wagner, S.; Ranville, J. F.; Hofmann, T. Release of $\mathrm{TiO}_{2}$ nanoparticles from sunscreens into surface waters: A one-year survey at the old danube recreational lake. Environ. Sci. Technol. 2014, 48, 5415-5422.

(32) Kaegi, R.; Englert, A.; Gondikas, A.; Sinnet, B.; von der Kammer, F.; Burkhardt, M. Release of $\mathrm{TiO}_{2}-(\mathrm{Nano})$ particles from construction and demolition landfills. NanoImpact. 2017, 8, 73-79.

(33) Maiga, D. T.; Mamba, B. B.; Msagati, T. A. M. Distribution profile of titanium dioxide nanoparticles in South African aquatic systems. Water Supply 2020, 20, 516-528.

(34) Kaegi, R.; Ulrich, A.; Sinnet, B.; Vonbank, R.; Wichser, A.; Zuleeg, S.; Simmler, H.; Brunner, S.; Vonmont, H.; Burkhardt, M.; Boller, M. Synthetic TiO2 nanoparticle emission from exterior facades into the aquatic environment. Environ. Pollut. 2008, 156, 233-239.

(35) Baalousha, M.; Wang, J.; Nabi, M. M.; Loosli, F.; Valenca, R.; Mohanty, S. K.; Afrooz, N.; Cantando, E.; Aich, N. Stormwater green infrastructures retain high concentrations of $\mathrm{TiO}_{2}$ engineered (nano)particles. J. Hazard. Mater. 2020, 392, 122335.

(36) Brunner, P. H.; Rechberger, H. Handbook of material flow analysis : for environmental, resource, and waste engineers; 2016, DOI: $10.1201 / 9781315313450-4$

(37) Nowack, B. Evaluation of environmental exposure models for engineered nanomaterials in a regulatory context. NanoImpact 2017, $8,38-47$.

(38) Keller, A. A.; Lazareva, A. Predicted Releases of Engineered Nanomaterials: From Global to Regional to Local. Environ. Sci. Technol. Lett. 2013, 1, 65-70.

(39) Keller, A. A.; Vosti, W.; Wang, H.; Lazareva, A. Release of engineered nanomaterials from personal care products throughout their life cycle. J. Nanopart. Res. 2014, 16, 2489.

(40) Ding, R.; Li, L.; Yang, P.; Luo, L.; Li, L.; Wang, Q. Assessing the environmental occurrence and risk of nano-silver in Hunan, China using probabilistic material flow modeling. Sci. Total Environ. 2019, $658,1249-1255$.

(41) Suzuki, S.; Part, F.; Matsufuji, Y.; Huber-Humer, M. Modeling the fate and end-of-life phase of engineered nanomaterials in the Japanese construction sector. Waste Manage. 2018, 72, 389-398.

(42) Song, R.; Qin, Y.; Suh, S.; Keller, A. A. Dynamic Model for the Stocks and Release Flows of Engineered Nanomaterials. Environ. Sci. Technol. 2017, 51, 12424-12433.

(43) Lazareva, A.; Keller, A. A. Estimating potential life cycle releases of engineered nanomaterials from wastewater treatment plants. ACS Sustainable Chem. Eng. 2014, 2, 1656-1665.

(44) Gottschalk, F.; Lassen, C.; Kjoelholt, J.; Christensen, F.; Nowack, B. Modeling flows and concentrations of nine engineered nanomaterials in the Danish environment. Int. J. Environ. Res. Public Health 2015, 12, 5581-5602.

(45) Wigger, H.; Nowack, B. Material-specific properties applied to an environmental risk assessment of engineered nanomaterials- 
implications on grouping and read-across concepts. Nanotoxicology 2019, 623

(46) Adam, V.; Caballero-Guzman, A.; Nowack, B. Considering the forms of released engineered nanomaterials in probabilistic material flow analysis. Environ. Pollut. 2018, 243, 17-27.

(47) Sun, T. Y.; Bornhöft, N. A.; Hungerbühler, K.; Nowack, B. Dynamic Probabilistic Modeling of Environmental Emissions of Engineered Nanomaterials. Environ. Sci. Technol. 2016, 50, 47014711.

(48) Wang, Y.; Nowack, B. Dynamic probabilistic material flow analysis of nano- $\mathrm{SiO}_{2}$, nano iron oxides, nano- $\mathrm{CeO}_{2}$, nano- $\mathrm{Al}_{2} \mathrm{O}_{3}$, and quantum dots in seven European regions. Environ. Pollut. 2018, 235, 589-601.

(49) Rajkovic, S.; Bornhöft, N. A.; van der Weijden, R.; Nowack, B.; Adam, V. Dynamic probabilistic material flow analysis of engineered nanomaterials in European waste treatment systems. Waste Manage. 2020, 113, 118-131.

(50) ANSES Elements issus des déclarations des substances à l'état nanoparticulaire; 2016 [accessed 2021 Jan 6]. https://www.ecologie. gouv.fr/sites/default/files/2016-11 - Rapport R-nano 2016.pdf

(51) Wigger, H.; Wohlleben, W.; Nowack, B. Redefining environmental nanomaterial flows: Consequences of the regulatory nanomaterial definition on the results of environmental exposure models. Environ. Sci.: Nano 2018, 5, 1372-1385.

(52) Auffan, M.; Pedeutour, M.; Rose, J.; Masion, A.; Ziarelli, F.; Borschneck, D.; Chaneac, C.; Botta, C.; Chaurand, P.; Labille, J.; Bottero, J.-Y. Structural degradation at the surface of a $\mathrm{TiO}_{2}$-based nanomaterial used in cosmetics. Environ. Sci. Technol. 2010, 44, 2689-2694.

(53) Netherlands Food and Consumer Product Safety Authority Opinion on possible health effects of the food additive titanium dioxide (E171); 2019, DOI: 10.5281/zenodo.3598296.

(54) Adams, R. Conference delegates discuss long-term consequences of the $\mathrm{TiO}_{2}$ price spike. Focus Pigm. 2013, 2013, 1-4.

(55) DuPont Nanomaterial Risk Assessment Worksheet. DuPont Light Stabilizer for use as a polymer additives; 2013. https://www.dupont. com

(56) Coll, C.; Notter, D.; Gottschalk, F.; Sun, T.; Som, C.; Nowack, B. Probabilistic environmental risk assessment of five nanomaterials (nano- $\mathrm{TiO}_{2}$, nano-Ag, nano- $\mathrm{ZnO}, \mathrm{CNT}$, and fullerenes). Nanotoxicology 2016, 10, 436-444.

(57) Labille, J.; Catalano, R.; Slomberg, D.; Motellier, S.; Pinsino, A.; Hennebert, P.; Santaella, C.; Bartolomei, V. Assessing Sunscreen Lifecycle to Minimize Environmental Risk Posed by Nanoparticulate UV-Filters - A Review for Safer-by-Design Products. Front. Environ. Sci. 2020, 8, 1-25.

(58) Pan, Z.; Lee, W.; Slutsky, L.; Clark, R. A. F.; Pernodet, N.; Rafailovich, M. H. Adverse effects of titanium dioxide nanoparticles on human dermal fibroblasts and how to protect cells. Small 2009, 5, 511-520.

(59) Foltête, A. S.; Masfaraud, J. F.; Bigorgne, E.; Nahmani, J.; Chaurand, P.; Botta, C.; Labille, J.; Rose, J.; Férard, J. F.; Cotelle, S. Environmental impact of sunscreen nanomaterials: Ecotoxicity and genotoxicity of altered $\mathrm{TiO} 2$ nanocomposites on Vicia faba. Environ. Pollut. 2011, 159, 2515-2522.

(60) Fouqueray, M.; Dufils, B.; Vollat, B.; Chaurand, P.; Botta, C.; Abacci, K.; Labille, J.; Rose, J.; Garric, J. Effects of aged TiO2 nanomaterial from sunscreen on Daphnia magna exposed by dietary route. Environ. Pollut. 2012, 163, 55-61.

(61) Fouqueray, M.; Noury, P.; Dherret, L.; Chaurand, P.; Abbaci, K.; Labille, J.; Rose, J.; Garric, J. Exposure of juvenile Danio rerio to aged $\mathrm{TiO} 2$ nanomaterial from sunscreen. Environ. Sci. Pollut. Res. 2013, 20, 3340-3350.

(62) Lapied, E.; Nahmani, J. Y.; Moudilou, E.; Chaurand, P.; Labille, J.; Rose, J.; Exbrayat, J. M.; Oughton, D. H.; Joner, E. J. Ecotoxicological effects of an aged $\mathrm{TiO} 2$ nanocomposite measured as apoptosis in the anecic earthworm Lumbricus terrestris after exposure through water, food and soil. Environ. Int. 2011, 37, 11051110.
(63) Ma, H.; Lenz, K. A.; Gao, X.; Li, S.; Wallis, L. K. Comparative toxicity of a food additive $\mathrm{TiO}_{2}$, a bulk $\mathrm{TiO}_{2}$, and a nano-sized P25 to a model organism the nematode C. elegans. Environ. Sci. Pollut. Res. 2019, 26, 3556-3568.

(64) Proquin, H.; Rodríguez-Ibarra, C.; Moonen, C. G. J.; Urrutia Ortega, I. M.; Briedé, J. J.; de Kok, T. M.; van Loveren, H.; Chirino, Y. I. Titanium dioxide food additive (E171) induces ROS formation and genotoxicity: contribution of micro and nano-sized fractions. Mutagenesis 2017, 32, 139-149.

(65) Dorier, M.; Béal, D.; Marie-Desvergne, C.; Dubosson, M.; Barreau, F.; Houdeau, E.; Herlin-Boime, N.; Carriere, M. Continuous in vitro exposure of intestinal epithelial cells to E171 food additive causes oxidative stress, inducing oxidation of DNA bases but no endoplasmic reticulum stress. Nanotoxicology 2017, 11, 751-711.

(66) Wyrwoll, A. J.; Lautenschläger, P.; Bach, A.; Hellack, B.; Dybowska, A.; Kuhlbusch, T. A. J.; Hollert, H.; Schäffer, A.; Maes, H. M. Size matters - The phototoxicity of $\mathrm{TiO}_{2}$ nanomaterials. Environ. Pollut. 2016, 208, 859-867.

(67) Meesters, J. A. J.; Koelmans, A. A.; Quik, J. T. K.; Hendriks, A. J.; Van De Meent, D. Multimedia modeling of engineered nanoparticles with simpleBox4nano: Model definition and evaluation. Environ. Sci. Technol. 2014, 48, 5726-5736.

(68) Liu, H. H.; Cohen, Y. Multimedia environmental distribution of engineered nanomaterials. Environ. Sci. Technol. 2014, 48, 32813292.

(69) Garner, K. L.; Suh, S.; Keller, A. A. Assessing the Risk of Engineered Nanomaterials in the Environment: Development and Application of the nanoFate Model. Environ. Sci. Technol. 2017, 51, $5541-5551$.

(70) Liu, H. H.; Surawanvijit, S.; Rallo, R.; Orkoulas, G.; Cohen, Y. Analysis of nanoparticle agglomeration in aqueous suspensions via constant-number Monte Carlo simulation. Environ. Sci. Technol. 2011, 45, 9284-9292.

(71) Lange, T.; Schneider, P.; Schymura, S.; Franke, K. The Fate of Anthropogenic Nanoparticles, $\mathrm{nTiO}_{2}$ and $\mathrm{nCeO}_{2}$, in Waste Water Treatment. Water. 2020, 12, 2509.

(72) Venkatesan, A. K.; Reed, R. B.; Lee, S.; Bi, X.; Hanigan, D.; Yang, Y.; Ranville, J. F.; Herckes, P.; Westerhoff, P. Detection and Sizing of Ti-Containing Particles in Recreational Waters Using Single Particle ICP-MS. Bull. Environ. Contam. Toxicol. 2018, 100, 120-126.

(73) Labille, J.; Slomberg, D.; Catalano, R.; Robert, S.; ApersTremelo, M. L.; Boudenne, J. L.; Manasfi, T.; Radakovitch, O. Assessing UV filter inputs into beach waters during recreational activity: A field study of three French Mediterranean beaches from consumer survey to water analysis. Sci. Total Environ. 2020, 706, 136010.

(74) Johnson, A. C.; Bowes, M. J.; Crossley, A.; Jarvie, H. P.; Jurkschat, K.; Jürgens, M. D.; Lawlor, A. J.; Park, B.; Rowland, P.; Spurgeon, D.; Svendsen, C.; Thompson, I. P.; Barnes, R. J.; Williams, R. J.; Xu, N. An assessment of the fate, behaviour and environmental risk associated with sunscreen $\mathrm{TiO} 2$ nanoparticles in UK field scenarios. Sci. Total Environ. 2011, 409, 2503-2510. 